\title{
KERTAS LABEL KOLORIMETRIK DENGAN EKSTRAK UBI UNGU SEBAGAI INDIKATOR PADA KEMASAN PINTAR UNTUK MENDETEKSI KESEGARAN SUSU
}

\author{
Cuk Imawan ${ }^{1}$, Rizka Fitriana ${ }^{1}$, Arie Listyarini ${ }^{1}$, Wafa Sholihah ${ }^{1}$, \\ dan Wiwik Pudjiastuti ${ }^{2}$ \\ ${ }^{1}$ Departemen Fisika, FMIPA Universitas Indonesia \\ Kampus UI Depok 16424, Indonesia \\ ${ }^{2}$ Balai Besar Kimia dan Kemasan, Kementerian Perindustrian RI \\ Jl. Balai Kimia I Pekayon, Pasar Rebo, Jakarta Timur \\ E-mail: cuk.imawan@sci.ui.ac.id
}

Received: 7 Desember 2017; revised: 11 April 2018; accepted: 12 April 2018

\begin{abstract}
ABSTRAK
KERTAS LABEL KOLORIMETRIK DENGAN EKSTRAK UBI UNGU SEBAGAI INDIKATOR PADA KEMASAN PINTAR UNTUK MENDETEKSI KESEGARAN SUSU. Produk susu sangat rentan terhadap penurunan kualitas yang dapat disebabkan karena faktor penyimpanan, padahal kualitas susu sangat penting untuk diperhatikan sebelum dikonsumsi. Pada penelitian ini dikembangkan label kolorimetrik sebagai indikator pada kemasan pintar yang dapat mendeteksi kualitas susu secara sederhana dan murah. Label kolorimetrik dibuat dari kertas selulosa dan ekstrak Ipomoea batatas sebagai zat warna alami untuk mendeteksi kualitas susu. Label dibuat dengan variasi $\mathrm{pH}$ ekstrak $\mathrm{pH} 2, \mathrm{pH} \mathrm{7,} \mathrm{dan} \mathrm{pH} 11$. Pengujian label dilakukan untuk kondisi penyimpanan suhu pada temperatur $4{ }^{\circ} \mathrm{C}, 23{ }^{\circ} \mathrm{C}$ dan $40{ }^{\circ} \mathrm{C}$ selama waktu 48 jam. Perubahan warna label difoto digital dan kemudian dihitung dengan analisis warna RGB. Hasil eksperimen menunjukkan label kolorimetrik dengan ekstrak zat warna $\mathrm{pH} 2$ mengalami perubahan warna dari merah muda ke merah keunguan, $\mathrm{pH} 7$ berubah warna dari ungu ke ungu terang agak kemerahan, dan $\mathrm{pH} 11$ berubah warna dari biru keabuan menjadi terang kekuningan setelah 48 jam. Dengan demikian label kolorimetrik dengan ekstrak zat warna $\mathrm{pH} 11$ paling baik untuk mendeteksi kesegaran susu, karena mengalami perubahan warna yang paling kontras. Penelitian ini menunjukkan bahwa label kolorimerik berbahan dasar ekstrak Ipomoea batatas baik untuk digunakan sebagai indikator pada kemasan pintar untuk mendeteksi kesegaran susu secara visual dan sederhana.
\end{abstract}

Kata kunci : label kolorimetrik, kemasan pintar, kesegaran susu

ABSTRACT

PAPER-BASED COLORIMETERIC LABEL USING SWEET POTATO EXTRACT AS MILK FRESHNESS INDICATOR IN SMART PACKAGING. Dairy products are particularly susceptible to quality degradation because of storage factors, yet the milk quality is very important to be considered before being consumed. This research has been developed to utilize colorimetric label as an indicator in smart packaging that can detect milk quality with the simple and cheap method. Colorimetric labels are made from cellulose paper and lpomoea batatas extract as natural dyes to detect milk quality. Labels with $\mathrm{pH}$ variations of extracts 2,7 , and 11 were tested for milk conditions stored at $4{ }^{\circ} \mathrm{C}, 23^{\circ} \mathrm{C}$, and $40{ }^{\circ} \mathrm{C}$ for 48 hours. The label color change was photographed digitally and then was calculated using RGB color analysis. The results showed that colorimetric labels with $\mathrm{p} \mathrm{H} 2$ dye extracts had a discoloration from pink to purplish red, $\mathrm{pH} 7$ changed color from purple to bright purple instead of reddish, and $\mathrm{pH} 11$ changed color from grayish blue to light yellow after 48 hours of detecting milk. Thus, in this work, the colorimetric label with $\mathrm{pH} 11$ dye extract is the best for detecting the freshness of milk, as it undergoes the most contrasting color changes. This research also revealed that colorimetric label based on Ipomoea batatas extract is good to be used as an indicator to detect milk freshness visually and simply in smart packaging.

Key words : colorimetric label, smart packaging, milk freshness 


\section{PENDAHULUAN}

Produk susu sangat mudah mengalami penurunan kualitas yang disebabkan oleh kekurangan pada kondisi penyimpanan. Penurunan kualitas susu ditandai dari perubahan warna, kekentalan, rasa, dan bau yang sebanding dengan jumlah pertumbuhan mikroorganisme dari susu tersebut. Mikroorganisme yang menyebabkan susu basi adalah bakteri asam laktat atau biasa disebut LAB (Lactic Acid Bacteria) (Lakade, Sundar, dan Shetty 2017).

Pertumbuhan $L A B$ menghasilkan pertambahan gas yang dikeluarkan oleh susu tersebut. Semakin banyak gas yang dikeluarkan maka semakin rendah kualitas susu tersebut atau dikatakan mengalami proses pembusukan. Susu yang segar atau basi dapat dibedakan dengan cara mendeteksi gas yang dikeluarkan. Jika pada daging yang mengalami proses pembusukan mengeluarkan gas ammonia, susu yang basi mengeluarkan gas yang berbau asam. Oleh karena itu, untuk mendeteksi susu yang basi dapat dilakukan dengan cara mengukur peningkatan uap asam yang dikeluarkan oleh susu (Kulchan et al. 2016).

Berbagai metode untuk mendeteksi kesegaran susu ini telah banyak dikembangkan. Dari mulai metode yang sederhana yakni dengan pengukuran kadar keasaman susu dengan indikator $\mathrm{pH}$ (Zhang, Lu, dan Chen 2014) lalu dengan metode mengukur konsentrasi gas yang dikeluarkan susu dengan serangkaian sensor gas (Haugen et al. 2006), hingga menggunakan Radio Frequency Identification atau RFID (Kant et al. 2017). Metode pengukuran kualitas susu dengan memanfaatkan sensor seperti ini memerlukan sistem yang rumit dan memerlukan banyak komponen elektronik hingga pemrosesan sinyal dalam pengambilan keputusannya. Metode ini memerlukan biaya yang mahal dan kurang praktis dalam penerapan kesehariannya terutama untuk kebutuhan penjualan susu di pasar swalayan.

Pada penelitian ini dikembangkan metode kolorimetri untuk mendeteksi kesegaran susu yaitu dengan pengembangan label indikator. Metode kolorimetri akhir-akhir ini banyak diteliti untuk aplikasi kesehatan (Devarayan dan Kim 2015) dan kemasan makanan (Rukchon et al. 2014; Nopwinyuwong, Trevanich, dan Suppakul 2010) karena cara kerjanya yang praktis, sederhana, murah dan dapat mengukur langsung obyek yang dideteksi. Ubi ungu adalah bahan alam yang banyak mengandung senyawa antosianin dan memiliki warna yang sangat sensitif terhadap perubahan $\mathrm{pH}$ (Choi et al. 2017). Kesegaran susu dapat dideteksi salah satunya dengan mengukur perubahan $\mathrm{pH}$ susu. Di samping itu, susu yang mengalami proses pembusukan mengeluarkan gas asam sehingga dapat dideteksi oleh antosianin yang sensitif terhadap perubahan $\mathrm{pH}$ lingkungan. Oleh sebab itu pada penelitian ini dikembangkan label indikator yang dibuat dari ekstrak ubi ungu untuk mendeteksi kesegaran susu dengan metode kolorimetri dan tanpa kontak dengan susu yang diukurnya.

\section{BAHAN DAN METODE}

\section{Bahan}

Material utama yang digunakan sebagai bahan dasar pembentuk label kolorimetri dalam eksperimen ini adalah Ipomoea batatas (ubi ungu) dan kertas saring selulosa Whatman nomor 1. Sebagai bahan uji label, digunakan susu pasteurisasi yang dibeli dari pasar swalayan.

\section{Pembuatan Ekstrak dan Uji Perubahan Warna Ekstrak Terhadap pH}

Persiapan pembuatan ekstrak dimulai dengan mencuci ubi ungu hingga bersih kemudian dipotong kecil-kecil. Potongan ubi ungu ini kemudian ditimbang sebanyak $80 \mathrm{~g}$ kemudian dihancurkan bersama $100 \mathrm{~mL}$ pelarut etanol dan aquades (7:3). Kemudian larutan asam klorida $(\mathrm{HCl})$ ditambahkan ke dalam campuran tersebut sampai pH larutan menjadi 2. Setelah itu larutan disimpan dalam botol gelap dan didiamkan pada suhu $5{ }^{\circ} \mathrm{C}$. Setelah waktu 24 jam, larutan ekstrak disaring dengan menggunakan kertas Whatman no 41. Supernatan yang dihasilkan disimpan dalam botol gelap dan digunakan sebagai ekstrak zat warna alam ubi ungu. Sebagian ekstrak diuji perubahan warnanya terhadap $\mathrm{pH}$ dengan cara menambahkan larutan buffer $\mathrm{pH} 2-\mathrm{pH} 11$ ke dalam ekstrak ubi ungu. Kemudian ekstrak dengan berbagai kondisi $\mathrm{pH}$ tersebut dianalisis dengan menggunakan spektrofotometer UV-Vis Genesys 10D Thermo Scientific.

\section{Preparasi Label Indikator}

Sebagai matriks label kolorimetri digunakan kertas selulosa yaitu kertas Whatman no 1 cat. 1001. Kertas tersebut dipotong dengan ukuran $3 \mathrm{~cm} \times 1 \mathrm{~cm}$ lalu $1 / 3$ bagian kertas selulosa dicelupkan ke dalam ekstrak ubi ungu dengan $\mathrm{pH}$ 2, $\mathrm{pH} 7$, dan $\mathrm{pH}$ 11. Ekstrak dengan $\mathrm{pH} 7$ dan $\mathrm{pH} 11$ didapatkan dengan menambahkan $\mathrm{NaOH}$. Pewarnaan label dilakukan dengan cara mencelupkan potongan kertas ke dalam ekstrak selama 5 detik, kemudian mengeringkannya di suhu ruang. 


\section{Pengujian Label Kolorimetri}

Kemampuan label untuk mendeteksi kesegaran susu diuji dengan cara meletakkan label ke dalam botol kaca transparan bertutup yang telah diisi dengan susu sebanyak $30 \mathrm{~mL}$. Label indikator digantungkan pada tutup botol dan tidak bersentuhan langsung dengan cairan susu. Jarak antara label dengan susu adalah kurang lebih $5 \mathrm{~cm}$. Perlakuan uji serupa disiapkan untuk pengamatan penyimpanan susu pada suhu $4{ }^{\circ} \mathrm{C}$ (refrigerator), suhu $23^{\circ} \mathrm{C}$ (suhu ruang) dan suhu $40^{\circ} \mathrm{C}$ (oven). Perubahan warna label indikator akibat adanya pembusukan susu diamati setelah waktu penyimpanan selama 48 jam pada masing-masing kondisi. Warna label indikator difoto dengan menggunakan kamera Canon EOS 750D dan intensitas komponen Merah (Red), Hijau (Green), dan Biru (Blue) atau yang dikenal sebagai $R G B$ warnanya dianalisis dengan menggunakan program ImageJ. Nilai RGB total dihitung dengan menggunakan persamaan :

$R G B$ total $=$

$\sqrt{0.299\left(R^{2}\right)+0.587\left(G^{2}\right)+0.114\left(B^{2}\right)}$

\section{HASIL DAN PEMBAHASAN}

\section{Pengaruh pH pada Warna Ekstrak}

Larutan ekstrak yang dikondisikan dengan larutan buffer pada $\mathrm{pH} 2$ sampai $\mathrm{pH} 11$ mengalami perubahan warna, seperti ditunjukkan pada Gambar 1. Secara visual, warna larutan ekstrak dapat dikelompokkan ke dalam tiga daerah $\mathrm{pH}$. Pada daerah $\mathrm{pH} 2$ sampai $\mathrm{pH} 6$ warna dasar larutan ekstrak adalah merah. Warna merah semakin menjadi terang dengan semakin besarnya nilai $\mathrm{pH}$. Kemudian pada daerah $\mathrm{pH} 7$ sampai $\mathrm{pH}$ 9, warna dasar larutan lebih ke ungu. Warna larutan kemudian berubah ke warna dasar biru ketika dikondisikan di daerah $\mathrm{pH} 10$ sampai $\mathrm{pH}$ 11. Perubahan warna larutan ekstrak yang sentitif terhadap $\mathrm{pH}$ mulai dari $\mathrm{pH}$ asam sampai $\mathrm{pH}$ basa seperti ini telah dilaporkan oleh peneliti-peneliti lainnya untuk ekstrak ubi ungu (Choi et al. 2017), kubis merah (Silva-Pereira et al. 2015), dan kulit anggur (Ma dan Wang 2016). Hasil ini menunjukkan bahwa ekstrak ubi ungu mengandung pigmen antosianin.

Karakterisasi larutan ekstrak dengan menggunakan spektrofotometer UV-vis menunjukkan bahwa absorbansi maksimum dari kondisi $\mathrm{pH} 2$ terjadi pada panjang gelombang $530 \mathrm{~nm}$, nilai ini bergeser ke panjang gelombang yang lebih besar dengan semakin besarnya $\mathrm{pH}$ ekstrak, Gambar 2. Pada daerah pH 2 sampai $\mathrm{pH} 6$ pergeseran panjang gelombang untuk nilai absorbansi maksimum tidak terlalu besar, tetapi dengan semakin besarnya nilai $\mathrm{pH}$, menyebabkan nilai absorbansinya semakin mengecil. Fenomena ini secara visual teramati dengan semakin terangnya warna merah larutan ekstrak ketika nilai $\mathrm{pH}$ berubah dari $\mathrm{pH} 2$ ke $\mathrm{pH}$ 6. Absorbsi yang terjadi pada daerah $\mathrm{pH} 7$ sampai $\mathrm{pH} 9$ berada pada panjang gelombang sekitar $550 \mathrm{~nm}$ yang berarti menyerap warna hijau sehingga menghasilkan warna komplementer ungu seperti yang terlihat visual untuk larutan ekstraknya. Larutan ekstrak pada $\mathrm{pH} 10$ sampai $\mathrm{pH} 11$ menunjukkan puncak absorbsi terjadi pada panjang gelombang sekitar $600 \mathrm{~nm}$ atau menyerap warna oranye dan menghasilkan warna komplementer biru. Gambar 3 menunjukkan spektrum UV-vis dari larutan ekstrak untuk tiga daerah warna yang diwakili oleh kondisi ekstrak di pH 2, pH 7 dan $\mathrm{pH} 11$.

Stabilitas Warna Label Terhadap Temperatur Susu segar memiliki nilai pH 6,3 sampai pH 6,8 dan tidak mengalami perubahan warna, rasa, bau dan kekentalan, sesuai dengan SNI 3141.1:2011 - Susu segar. Oleh sebab itu di dalam penelitian ini diuji masing-masing perwakilan dari tiga daerah $\mathrm{pH}$ ekstrak yaitu $\mathrm{pH} 2$, $\mathrm{pH} 7$ dan $\mathrm{pH} 11$, untuk dijadikan sebagai label kesegaran. Label yang telah disiapkan memiliki warna yang agak berbeda jika dibandingkan warna dari larutan ekstraknya, seperti yang diperlihatkan di Gambar 4.

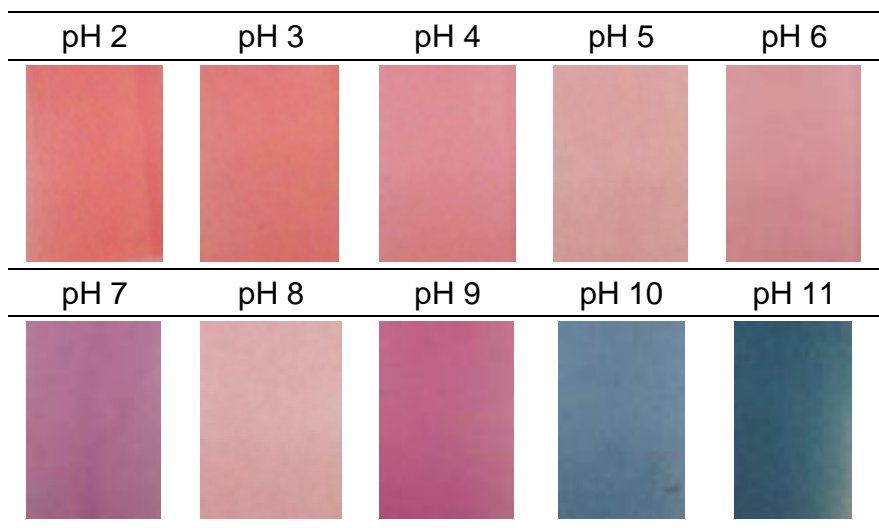

Gambar 1. Perubahan warna ekstrak ubi ungu terhadap $\mathrm{pH}$ 


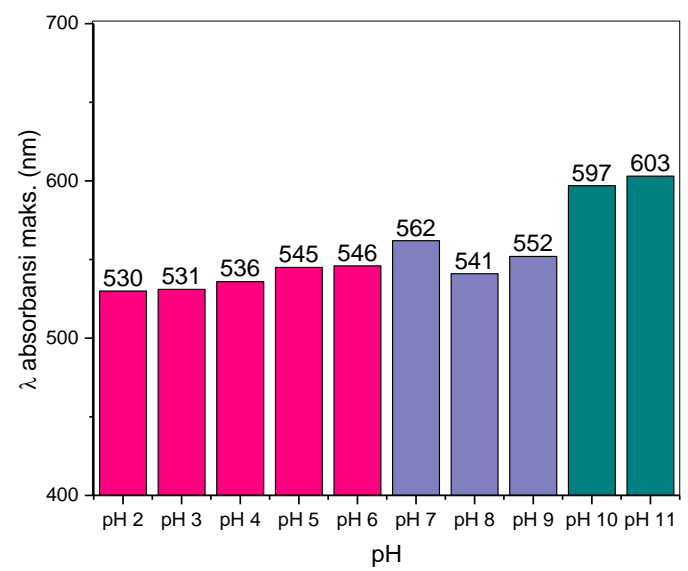

Gambar 2. Perubahan panjang gelombang untuk nilai absorbansi maksimum ekstrak terhadap $\mathrm{pH}$

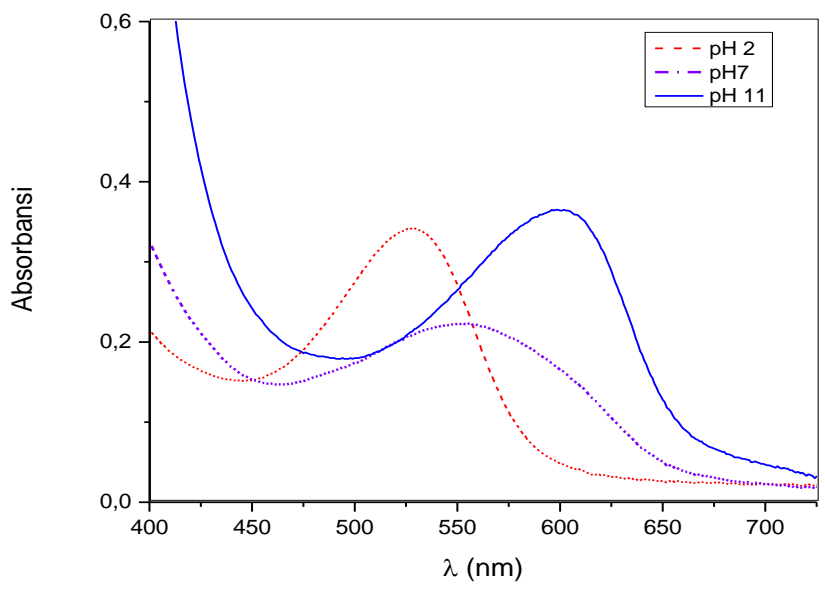

Gambar 3. Spektrum absorbansi UV-Vis dari ekstrak ubi ungu untuk $\mathrm{pH} 2, \mathrm{pH} 7$ dan $\mathrm{pH} 12$

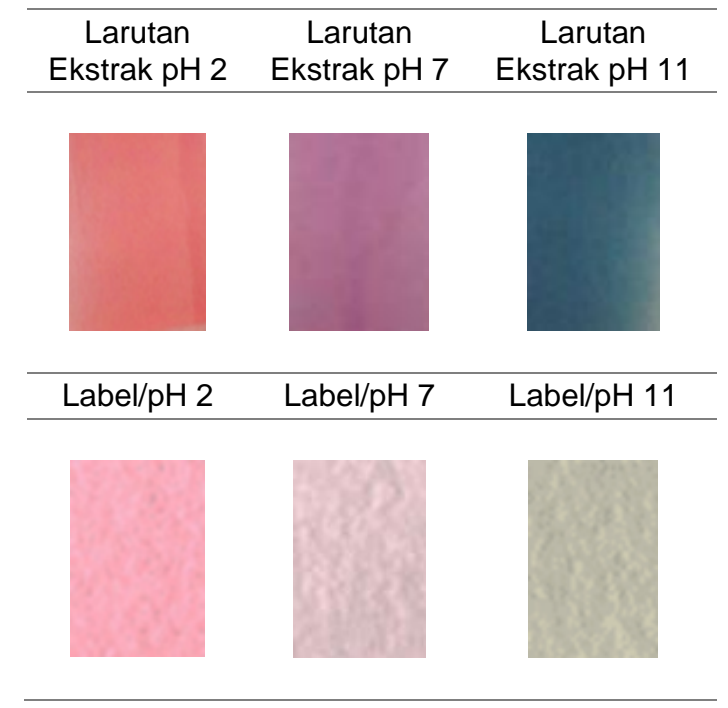

Gambar 4. Perbedaan warna larutan ekstrak dan warna label

Secara umum, warna dasar dari label masih sama dengan warna dasar ekstraknya, tetapi warna label lebih terang atau muda.

Hasil pengujian stabilitas warna label terhadap temperatur lingkungan sebagai simulasi kondisi penyimpanan susu diberikan pada Gambar 5. Nilai intensitas RGB total dari ketiga label tersebut terlihat sangat stabil, nilainya tidak berubah ketika diletakkan di kondisi temperatur $4{ }^{\circ} \mathrm{C}, 23^{\circ} \mathrm{C}$ dan $40^{\circ} \mathrm{C}$. Hal ini menunjukkan bahwa warna label dengan $\mathrm{pH}$ ekstrak $\mathrm{pH} 2$ 2, pH 7 dan $\mathrm{pH} 11$ sangat stabil dan dapat digunakan untuk mendeteksi kesegaran susu pada daerah temperatur penyimpanan $4{ }^{\circ} \mathrm{C}$ sampai dengan $40{ }^{\circ} \mathrm{C}$ tanpa harus dikoreksi karena perbedaan kondisi temperatur penyimpanan.

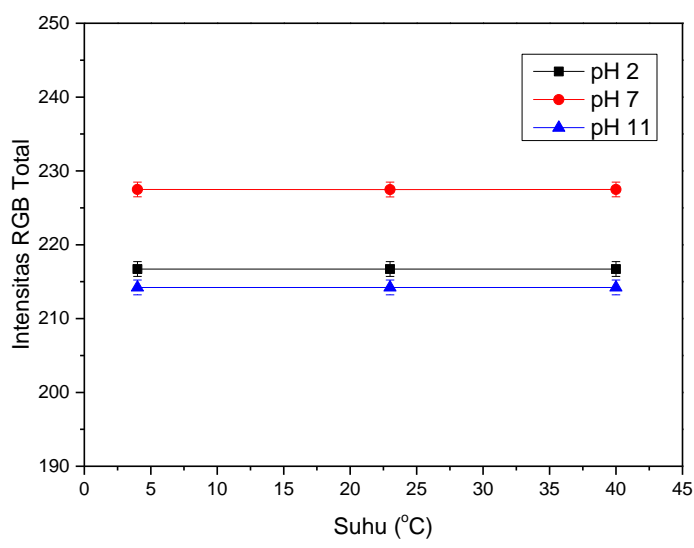

Gambar 5. Stabilitas warna label terhadap temperatur 
Respon Label Indikator pada kesegaran Susu

Pengujian label indikator dari ekstrak $\mathrm{pH}$ 2, $\mathrm{pH} 7$ dan $\mathrm{pH} 11$ pada susu ditunjukkan di Gambar 6. Kondisi penyimpanan susu adalah pada temperatur $4{ }^{\circ} \mathrm{C}, 23{ }^{\circ} \mathrm{C}$, dan $40^{\circ} \mathrm{C}$ dan gambar diambil setelah susu disimpan selama 48 jam. Eksperimen ini menunjukkan bahwa pada kondisi temperatur penyimpanan $4{ }^{\circ} \mathrm{C}$, waktu penyimpanan 48 jam belum membuat susu menjadi basi. Pada temperatur penyimpanan $23^{\circ} \mathrm{C}$, setelah waktu 48 jam, susu menunjukkan tanda mulai basi dan pada $48^{\circ} \mathrm{C}$, susu sudah menjadi basi yaitu ditandai dengan munculnya endapan yang menggumpal dan bau menyengat. Saat susu masih segar, $\mathrm{pH}$ susu ada di sekitar nilai $\mathrm{pH} 6$ sampai $\mathrm{pH}$ 7. Ketika susu mulai mengalami proses pembusukan, nilai $\mathrm{pH}$ susu akan menurun atau susu menjadi asam. Semakin asam, tingkat kesegaran susu semakin rendah dan menjadi basi ketika memiliki nilai pH sekitar 5 .

Pengukuran $\mathrm{pH}$ susu pada eksperimen ini menunjukkan, susu yang masih segar memiliki nilai $\mathrm{pH} 6,65$. Setelah mengalami penyimpanan selama 48 jam, susu yang disimpan pada temperatur $4{ }^{\circ} \mathrm{C}$ pengalami penurunan $\mathrm{pH}$ ke nilai 6,50 berarti masih segar (Lakade, Sundar, dan Shetty 2017). Pada suhu penyimpanan 23 ${ }^{\circ} \mathrm{C}$, pH susu terukur bernilai 6,00 dan untuk kondisi penyimpanan $40{ }^{\circ} \mathrm{C}$, susu telah mengalami penurunan $\mathrm{pH}$ menjadi 5,28. Pada temperatur penyimpanan $23{ }^{\circ} \mathrm{C}$, susu sudah mulai basi, tidak layak dikonsumsi dan pada temperatur penyimpanan $40{ }^{\circ} \mathrm{C}$ susu sudah sangat basi. Hasil eksperimen ini menunjukkan bahwa temperatur penyimpanan memiliki peran penting untuk menjaga kesegaran susu, semakin tinggi temperatur penyimpanan semakin cepat susu menjadi basi (Kulchan et al. 2016). Semakin tinggi temperatur penyimpanan akan memicu meningkatnya pertumbuhan mikroorganisme sehingga susu akan semakin mudah basi (Chen, Wei, dan Chen 2011).

Gambar 7 menunjukkan peta perubahan warna label ketika mendeteksi susu pada kondisi temperatur penyimpanan $4{ }^{\circ} \mathrm{C}, 23^{\circ} \mathrm{C}$ dan $40{ }^{\circ} \mathrm{C}$ setelah waktu 48 jam.

Pengujian label dari ekstrak $\mathrm{pH} 2$ memberikan hasil, warna label saat susu masih segar dan ketika susu sudah basi tidak menunjukkan perubahan warna yang berarti. Label pada awalnya berwarna merah muda dan setelah mendeteksi susu yang basi warnanya berangsur agak merah keunguan. Perubahan warna merah dari label menjadi merah keunguan disebabkan karena pigmen antosianin merasakan perubahan kondisi lingkungannya yang semula normal menjadi asam ketika susu menjadi basi, yaitu berkisar di $\mathrm{pH} 5$ pada temperatur penyimpanan $40^{\circ} \mathrm{C}$.

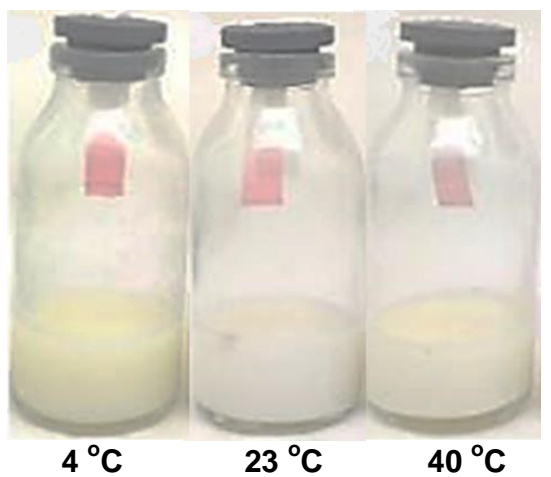

(a) Label/pH 2

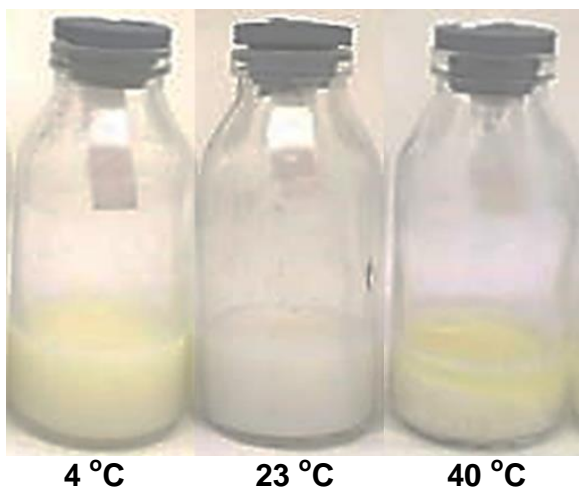

(b) $\mathrm{Label} / \mathrm{pH} 7$

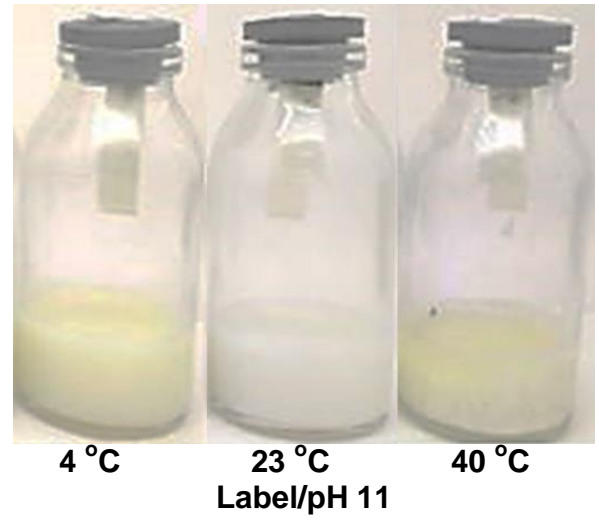

Gambar 6. Uji label pada susu dengan kondisi temperatur simpan yang berbeda. Foto diambil setelah waktu simpan 48 jam. 


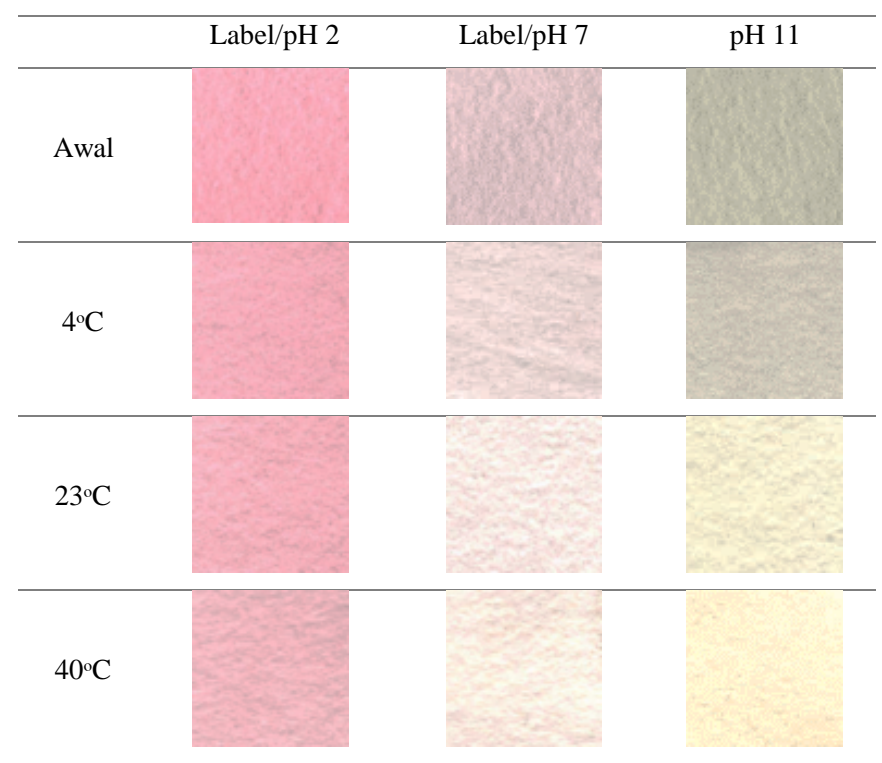

Gambar 7. Peta perubahan warna label indikator setelah 48 jam mendeteksi susu yang disimpan pada temperatur berbeda.

Argumentasi ini didukung oleh kenyataan bahwa saat nilai $\mathrm{pH}$ larutan ekstrak di angka 5, warna larutan menjadi merah muda keunguan seperti terlihat pada Gambar 1.

Label/ pH 7 ketika mendeteksi susu yang basi $\left(40^{\circ} \mathrm{C}\right)$, yang pada awalnya berwarna ungu berubah menjadi ungu terang agak kemerahan. Perubahan warna ini bersesuaian dengan perubahan warna ekstrak ketika dikondisikan dari $\mathrm{pH} 7$ berubah ke $\mathrm{pH}$ 5, Gambar 1. Perubahan warna menjadi sangat terang ini bersesuaian dengan hasil karakterisasi spektrum absorbsi larutan ekstrak yang mana pada kondisi $\mathrm{pH} 4$ dan 5, absorbansi ekstrak memiliki nilai paling rendah atau warna ekstrak menjadi paling terang dibandingkan dengan kondisi di nilai $\mathrm{pH}$ lainnya. Pada label/ $\mathrm{pH} 12$, warna label yang semula biru keabu-abuan sebelum mendeteksi susu atau saat mendeteksi susu segar berubah warna menjadi terang kekuningan ketika mendeteksi susu basi. Fenomena ini menunjukkan, pigmen ekstrak yang semula terkondisikan pada $\mathrm{pH} 11$ sebelum mendeteksi susu atau ketika mendeteksi susu segar, merasakan perubahan kondisi lingkungan menjadi asam di sekitar nilai $\mathrm{pH} 5$ ketika susu menjadi basi.

Kuantitas perubahan warna label indikator (Gambar 7) yang dianalisis dengan menggunakan ImageJ ditunjukkan di Gambar 8.

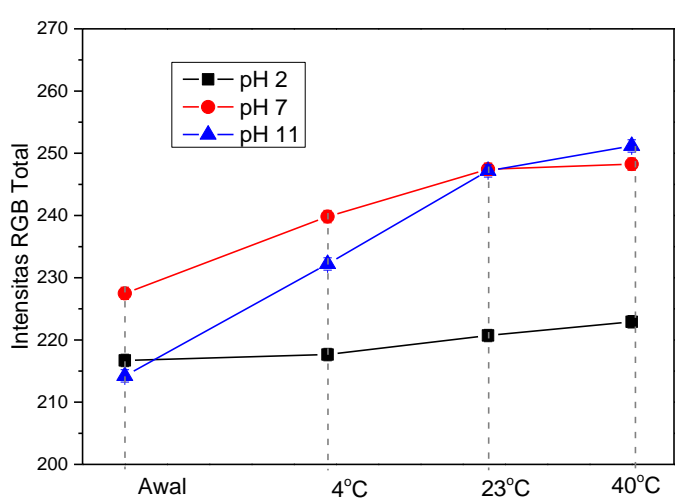

Gambar 8. Pengaruh temperatur simpan pada intensitas RGB total dari label setelah 48 jam mendeteksi susu.

Secara umum, intensitas $R G B$ total untuk ketiga label mengalami kenaikan nilai dari nilai $R G B$ total awal, sebelum label mendeteksi susu dan setelah label mendeteksi susu setelah 48 jam waktu penyimpanan untuk temperatur simpan $4{ }^{\circ} \mathrm{C}, 23{ }^{\circ} \mathrm{C}$ dan $40{ }^{\circ} \mathrm{C}$. Hasil ini bersesuaian dengan pengamatan visual yaitu warna label semakin memudar atau bertambah terang setelah mendeteksi susu. Label/pH 2 hanya mengalami kenaikan nilai $R G B$ total sangat 
kecil, sedangkan label/pH 11 mengalami kenaikan nilai yang sangat besar, sesuai dengan hasil pengamatan visual yang mana perubahan warna label/pH 11 sebelum dan setelah mendeteksi susu basi sangat kontras. Hasil ini menunjukkan bahwa label/pH 11 merupakan label indikator yang paling baik di antara label yang ada di eksperimen ini, untuk digunakan sebagai indikator kesegaran susu.

Berdasarkan hasil-hasil eksperimen ini yaitu mengamati kesegaran susu berdasarkan standar SNI 3141.1:2011 (SNI 3141.1: 2011) dengan mengukur $\mathrm{pH}$ susu dan uji organoleptik bersamaan dengan uji perubahan warna label indikator yang dibuat dari kertas selulosa dan ekstrak Ipomoea batatas (ubi ungu) disimpulkan bahwa susu segar dan susu basi dapat dideteksi secara langsung dengan label indikator ini. Label/pH 11 menunjukkan perbedaan warna yang paling kontras saat mendeteksi susu segar dan susu basi, Gambar 9. Dengan demikian label ini secara praktis dan sederhana dapat digunakan untuk mendeteksi kesegaran susu secara langsung yaitu hanya dengan mengamati warna label.

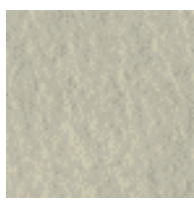

Susu segar

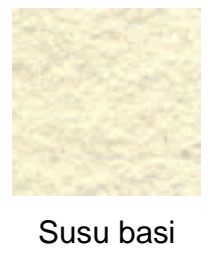

Gambar 9. Warna label/pH 11 untuk membedakan susu segar dan basi.

\section{KESIMPULAN}

Label indikator yang dibuat dari kertas selulosa dan ekstrak Ipomoea batatas (ubi ungu) dapat digunakan untuk mendeteksi kesegaran susu dengan cara mengamati perubahan warna label. Label yang memberikan perubahan warna ketika susu menjadi rusak adalah label dengan ekstrak ubi ungu yang dikondisikan pada $\mathrm{pH} 11$. Ketika susu masih segar, label berwarna biru keabuan dan setelah susu mengalami proses pembusukan, label berubah warna menjadi kuning. Hasil penelitian ini menunjukkan bahwa label kolorimetri yang terbuat dari kertas selulosa dengan ekstrak ubi ungu ini dapat digunakan sebagai indikator kemasan pintar untuk mendeteksi kesegaran susu.

\section{DAFTAR PUSTAKA}

Kulchan, R., W. Boonsupthip, T. Jinkarn dan P. Suppakul. 2016. "Developing a Novel
Colorimetric Indicator for Monitoring Rancidity Reaction and Estimating the Accelerated Shelf Life of OxygenSensitive Dairy Products" 23 (3): 1092-99.

Chen, T.R., Q.K. Wei, dan Y.J. Chen. 2011. "Pseudomonas Sp. and Hafnia Alvei Growth in UHT Milk at Cold Storage." Food Control 22 (5). Elsevier Ltd: 697701. doi:10.1016/j.foodcont.2010.10.004.

Choi, I., J. Y. Lee, M. Lacroix, dan J. Han. 2017. "Intelligent $\mathrm{pH}$ Indicator Film Composed of Agar/potato Starch and Anthocyanin Extracts from Purple Sweet Potato." Food Chemistry 218. Elsevier Ltd: 122-28. doi:10.1016/j.foodchem.2016.09.050.

Devarayan, K., dan B.S. Kim. 2015. "Reversible and Universal pH Sensing Cellulose Nanofibers for Health Monitor." Sensors and Actuators, B: Chemical 209. Elsevier B.V.: 281-86. doi:10.1016/j.snb.2014.11.120.

Haugen, J.E., K. Rudi, S. Langsrud, dan S. Bredholt. 2006. "Application of GasSensor Array Technology for Detection and Monitoring of Growth of Spoilage Bacteria in Milk: A Model Study" 565: 1016. doi:10.1016/j.aca.2006.02.016.

Indonesia, Standar Nasional. Badan Standardisasi Nasional. 2011. "Susu Segar-Bagian 1: Sapi."

Kant, Rajni, P K Prabhakar, S Samadder, dan P $P$ Srivastav. 2017. "Radio Frequency Based Sensor: An Innovative Detection Tool for Food Spoilage" 6 (4): 80-86.

Lakade, A.J., K. Sundar, dan P.H. Shetty. 2017. "LWT - Food Science and Technology Nanomaterial-Based Sensor for the Detection of Milk Spoilage." LWT - Food Science and Technology 75. Elsevier Ltd: 702-9. doi:10.1016/j.Iwt.2016.10.031.

Ma, Q., dan L. Wang. 2016. "Preparation of a Visual pH-Sensing Film Based on Tara Gum Incorporating Cellulose and Extracts from Grape Skins." Sensors and Actuators, B: Chemical 235. Elsevier B.V.: 401-7. doi:10.1016/j.snb.2016.05.107.

Nopwinyuwong, A., S. Trevanich, dan P. Suppakul. 2010. "Development of a Novel Colorimetric Indicator Label for Monitoring Freshness of Intermediate-Moisture Dessert Spoilage." Talanta 81 (3). Elsevier B.V.: $\quad 1126-32$. doi:10.1016/j.talanta.2010.02.008.

Rukchon, C., A. Nopwinyuwong, S. Trevanich, T. Jinkarn, dan Panuwat Suppakul. 2014. "Development of a Food Spoilage Indicator for Monitoring Freshness of Skinless Chicken Breast." Talanta 130. Elsevier: $\quad$ 547-54. doi:10.1016/j.talanta.2014.07.048.

Silva-Pereira, M.C., J.A. Teixeira, V.A. PereiraJunior, dan Ricardo Stefani. 2015. 
"Chitosan/corn Starch Blend Films with Extract from Brassica Oleraceae (Red Cabbage) as a Visual Indicator of Fish Deterioration." LWT - Food Science and Technology $61 \quad$ (1): 258-62. doi:10.1016/j.Iwt.2014.11.041.
Zhang, X., S. Lu, dan X. Chen. 2014. "A Visual pH Sensing Film Using Natural Dyes from Bauhinia Blakeana Dunn." Sensors and Actuators, B: Chemical 198. Elsevier B.V.: 268-73. doi:10.1016/j.snb.2014.02.094. 